\title{
Inhibitory Effects of Essential Oils for Controlling Phytophthora capsici
}

\author{
Yang Bi, He Jiang, Mary K. Hausbeck, and Jianjun J. Hao, Department of Plant Pathology, Michigan State University, East Lans-
} ing, MI

\begin{abstract}
Bi, Y., Jiang, H., Hausbeck, M. K., and Hao, J. J. 2012. Inhibitory effects of essential oils for controlling Phytophthora capsici. Plant Dis. 96:797803.

Essential oils (EOs) were studied in vitro and in vivo for inhibiting Phytophthora capsici. Mycelial growth of $P$. capsici was examined on EO-amended media or after exposing it to EO volatiles. The efficacy of EOs was determined by estimating the effective concentration for $50 \%$ inhibition of $P$. capsici mycelial growth $\left(\mathrm{EC}_{50}\right)$. Among 14 tested commercial products, oregano, palmarosa, and red thyme EOs had the lowest $\mathrm{EC}_{50}$ values $(<0.15 \mu \mathrm{g} / \mathrm{ml})$ for inhibiting the production and germination of sporangia and zoospores, and mycelial growth of $P$. capsici. The EOs had the same range of effect on inhibiting some mutant $P$. capsici isolates resistant to fluopicolide and zoxamide. $P$. cap-

sici population in soil was reduced by the three EOs. Zucchini (Cucurbita pepo) fruit were protected against $P$. capsici infection when they were sprayed with red thyme $(0.1 \mu \mathrm{g} / \mathrm{ml})$ or oregano and palmarosa $(0.2 \mu \mathrm{g} / \mathrm{ml})$ EOs. Zucchini seedling emergence was affected by oregano, but not by red thyme. Zucchini seedlings survived in $P$. capsiciinfested soil treated with red thyme at $0.1 \mu \mathrm{g} / \mathrm{ml}$, while all of the nontreated seedlings died. These results taken together suggest that oregano, red thyme, and palmarosa EOs may be potential components for integrated management of $P$. capsici.
\end{abstract}

Phytophthora capsici Leonian is a soilborne oomycete that can infect more than 45 species of vegetables, including cucurbitaceous and solanaceous crops such as pumpkin (Cucurbita moschata), zucchini (Cucurbita pepo), squash (Cucurbita maxima), and pepper (Capsicum spp.) $(3,16)$. This pathogen can cause fruit, crown, and root rot, and stem and leaf blight disease, and can result in catastrophic yield losses to a number of crops $(12,13,16,31)$. $P$. capsici can survive in soil and be dispersed as mycelia, zoospores, and oospores via irrigation water and rainfall $(16,31)$. Although fungicides are the primary means of control of $P$. capsici in vegetable production $(6,13,16,24)$, there are many considerations involved in their application, such as cost-effectiveness, development of fungicide resistance, efficacy due to resistance and pathogen adaptation $(6,24,31,32)$. More importantly, application of fungicide has drawn significant socio and environmental concerns, and may not be the first choice if other options are available $(14,17,19)$. In seeking tools for alternative disease management strategies, essential oils (EOs) have been studied in various target pathogens and can be used in an organic production system $(29,32,33,35,39)$.

An EO is a concentrated hydrophobic oily liquid derived from various aromatic plants (8). Historically, EOs have been used as fragrance and flavoring agents in food production, but their application is being expanded into other areas, such as food preservation, where their antimicrobial activities inhibit bacteria and yeasts $(8,36,40)$. Most EOs are derived from plants in the Lauraceae and Myrtaceae families $(8,33,37)$. EOs have also been studied as insecticides (9), fungicides $(1,4,20,23,29,33,36)$, and nematicides (25). Relative to other plant disease systems, few studies of EOs have been reported in oomycetes, such as $P$. cactorum (23), $P$. infestans (34), and $P$. citrophthora (11). EOs activity against $P$. capsici tests have been conducted in vitro, with a few examples of greenhouse or field studies (39). Previous studies confirm that EO has potential in Phytophthora disease management. However, to maximize the efficacy of EOs in P. capsici management, the products need to be studied further.

Corresponding author: Jianjun J. Hao, E-mail: jjhao@ msu.edu

Accepted for publication 21 December 2011.

http://dx.doi.org/10.1094/PDIS-11-11-0933

(C) 2012 The American Phytopathological Society
EOs such as oregano and red thyme have been studied for inhibition of $P$. infestans $(27,28,34)$, but palmarosa EO has not yet been evaluated. For $P$. capsici, a few studies have been conducted using, for example, EOs of Nandina domestica, Artemisia nilagirica, and Erigeron ramosus $(4,21,29,32,39)$. In these studies on $P$. capsici, efforts were focused on chemical composition analysis and in vitro antifungal activity of EOs, except for one study that investigated the effect of EO on pepper under greenhouse and field conditions (39). No study to date has examined the effects of EOs on the different growth stages of $P$. capsici and cucurbit hosts.

Use of the EOs for plant disease management is an accepted practice. One direction of studying EOs for their antimicrobial activities and disease control is that individual active compounds can be purified and applied to manage disease $(1,2,4,32)$. Some EOs have been extensively studied, and their major active ingredients corresponding to their antimicrobial activities have been well characterized. Furthermore, the active compounds, such as thymol, have been synthesized and marketed for disease control $(5,15,18)$. It has been observed in many situations that not only one or two compounds are responsible for antimicrobial activity, but a combination of compounds with synergistic effects is involved. While many of the individual active compounds have been identified, there may be others found in EOs that have yet to be identified or described. Similar to other products, for example Muscodor, there have been reports that combined materials can act differently than individual compounds (26). Thus the use of individual compounds may not be analogous to using EOs. Instead of isolating and synthesizing one compound or two, the whole essential oil(s) should be evaluated for disease control.

The objectives of this study were to (i) compare the efficacy among 14 EOs for inhibition of mycelial growth of $P$. capsici, (ii) study the efficacy of the most efficacious EOs on various stages of $P$. capsici development, (iii) evaluate EOs for their efficacy in reducing $P$. capsici populations in the soil, (iv) examine phytotoxicity of EOs to zucchini, and (v) evaluate the control of $P$. capsici infection on zucchini plants in the greenhouse.

\section{Materials and Methods}

Pathogen isolates, chemicals, and plant EOs. P. capsici isolates were from Michigan field-grown cucurbitaceous and solanaceous plants grown by the Hausbeck laboratory and characterized previously (13). Isolates 12889 (mating type A1), SP98 (mating type A2), and 9522 (mating type A1) were used in this study, and 
all three are sensitive to zoxamide, a conventional oomycete fungicide (13). Zoxamide-insensitive isolates R13-2 and R3-3 (6), and fluopicolide-resistant isolates derived from 12889, R25, R36, and R40 (24) were also included in this study. These isolates were grown and maintained on potato dextrose agar (PDA, EMD Chemicals, Gibbstown, NJ). Fourteen plant EOs were purchased from Frontier Natural Products Co-op (Norway, IA; Table 1). Zoxamide, a standard fungicide Gavel 75 DF (80\% active ingredient), was obtained from Gowan Company (Yuma, AZ) and used as a control for comparison. EOs and zoxamide were dissolved in dimethyl sulfoxide (DMSO) for stock solutions $(0.8$ and $1 \mathrm{mg} / \mathrm{ml}$, respectively) and stored at $4^{\circ} \mathrm{C}$ in the dark.

Effect of EOs on P. capsici biology. Assay on EO-amended media. Fourteen EOs (Table 1) were evaluated for their ability to inhibit $P$. capsici using an EO-amended PDA plate $(10 \mathrm{~cm}$ in diameter throughout the experiment) assay as described for fungicide studies (6). The EO, dissolved in DMSO, was added to a flask containing cooled PDA, a magnetic stir bar, and mixed on a hot plate stirrer for $1 \mathrm{~min}$ before the media was poured. In order to calculate $\mathrm{EC}_{50}$ values, defined as the effective concentration of $50 \%$ inhibition, a pilot experiment was conducted to determine the range of growth responses of $P$. capsici on PDA amended with each of the EOs at various concentrations. A dose-response curve was established based on the sensitivity, with four replicated plates per concentration. The experiment was conducted twice. The EO concentrations in media were adjusted from 0.025 to $0.8 \mu \mathrm{g} / \mathrm{ml}$ or from 0.02 to $0.6 \mu \mathrm{g} / \mathrm{ml}$, depending on their efficacy estimated from pilot tests. Zoxamide (0.02 to $0.6 \mu \mathrm{g} / \mathrm{ml})$ and DMSO (0.1\%) amended media were used for positive and negative controls, respectively. The final concentration of DMSO in agar media was adjusted to $0.1 \%$ ( $\mathrm{vol} / \mathrm{vol})$, a level determined to have no effect on $P$. capsici growth (6). This DMSO concentration was used throughout the study. An agar plug of each $P$. capsici culture $(5 \mathrm{~mm}$ diameter) was removed using a cork borer from the active margin of a colony grown on PDA, and placed at the center of a new petri plate $(100 \times 15 \mathrm{~mm})$ containing PDA amended with either EO, zoxamide, or DMSO only. After incubation at $25^{\circ} \mathrm{C}$ in the dark for 3 to 6 days, when the colony reached $7 \mathrm{~cm}$ in diameter for control plates (amended with DMSO only), colony diameter was measured perpendicularly with a ruler, and the two measurements were averaged for data analysis. Each treatment was replicated with four plates. All experiments were conducted twice.

To determine the effect of EOs on fungicide-resistant $P$. capsici isolates, a trial was set up to evaluate growth response of isolates 12889, R25, R36, R40, R13-2, and R3-3 on oregano- and red- thyme-amended PDA, using the method as described above. $\mathrm{EC}_{50}$ sensitivity values were expressed in $\mu \mathrm{g} / \mathrm{ml}$. Isolate sensitivity was determined by interpolation of the $50 \%$ intercept based on regression of the log concentration against the inhibition percent value of relative mycelia growth.

Assay with EO volatiles. A culture plug of each $P$. capsici isolate was placed in the center of a PDA plate. A sterile filter paper disc ( $8 \mathrm{~mm}$ diameter, Whatman no. 1, Fisher Scientific, Pittsburgh, PA), applied with $10 \mu \mathrm{l}$ of an EO at different concentrations, from 0.025 to $0.8 \mu \mathrm{g} / \mathrm{ml}$ or 0.02 to $0.6 \mu \mathrm{g} / \mathrm{ml}$, was placed in the center of the inside of the lid. A volume of $0.1 \%$ DMSO applied on the filter paper was used as a control. Plates were closed and sealed with Parafilm to reduce loss of EO via evaporation. Each treatment was replicated with four plates. The plates were placed in an incubator at $25^{\circ} \mathrm{C}$ in the dark for 3 to 6 days, after which the colony diameter was measured perpendicularly and the two measurements were averaged for data analysis. The experiment was conducted twice.

Spore production. P. capsici isolates 12889 and SP98 were used in this study. Two methods were used to test effects of EOs on sporangia and zoospore production. In the first method, a mycelial plug ( $5 \mathrm{~mm}$ diameter) of $P$. capsici, cut from the margin of a 3-dayold culture grown on PDA, was placed on V8 agar (6) amended with EO of either oregano, palmarosa, or red thyme, or the fungicide zoxamide. In the second method, volatiles of the three EOs were examined for inhibition of $P$. capsici zoospore formation, as described above. The concentrations used for oregano, palmarosa, red thyme, and zoxamide were 0.05 to $0.1,0.05$ to $0.2,0.05$ to 0.2 , and 0.02 to $0.6 \mu \mathrm{g} / \mathrm{ml}$, respectively. DMSO $(0.1 \%)$ was used as a control. Each treatment was replicated four times. The plates were incubated at $25^{\circ} \mathrm{C}$ in the dark. Sporangial and zoospore production of $P$. capsici were examined following the method described by Lamour and Hausbeck (22). After incubation under light (2,000 to $3,000 \operatorname{lux}$ ) for 2 to 3 days, $P$. capsici sporangia were obtained by flooding plates with sterile distilled water and scraping with a sterile glass spatula to make a spore suspension. Sporangia and zoospores were quantified with a hemacytometer. For ease of counting, zoospores were encysted by vortexing for $1 \mathrm{~min}$. Four replicate plates were used for each treatment. The experiment was conducted twice.

To examine the effect of EOs on oospore formation, $P$. capsici isolates 12889 (A1 mating type) and SP98 (A2 mating type) were co-cultured on $10 \%$ V8 medium amended with a range of concentrations of either EOs, zoxamide, or DMSO control (34). The plates were incubated in the dark at $25^{\circ} \mathrm{C}$ for about 15 days. The culture plates were homogenized with $10 \mathrm{ml}$ of sterile water in a

Table 1. Source of essential oils (EOs) and their inhibitory effect on Phytophthora capsici

\begin{tabular}{|c|c|c|c|c|}
\hline \multirow[b]{2}{*}{ Essential oil } & \multirow[b]{2}{*}{ Plant for EO extraction } & \multirow[b]{2}{*}{ Plant family } & \multicolumn{2}{|c|}{$\mathrm{EC}_{50}(\mu \mathrm{g} / \mathrm{ml})^{\mathrm{w}}$} \\
\hline & & & $\operatorname{Media}^{x}$ & Volatile \\
\hline Oregano & Origanum syriacum & Lamiaceae & $0.07 \mathrm{~d}$ & $0.09 \mathrm{~d}$ \\
\hline Palmarosa & Cymbopogon martini & Poaceae & $0.10 \mathrm{~d}$ & $0.15 \mathrm{~d}$ \\
\hline Red thyme & Thymus vulgaris & Lamiaceae & $0.14 \mathrm{~d}$ & $0.11 \mathrm{~d}$ \\
\hline Clove bud & Caryophyllus aromaticus & Myrtaceae & $0.14 \mathrm{~d}$ & $0.25 \mathrm{~d}$ \\
\hline Cinnamon leaf & Cinnamoтит zeylanicum & Lauraceae & $0.19 \mathrm{~cd}$ & $0.28 \mathrm{~d}$ \\
\hline Citronella java & Cymbopogon nardus & Poaceae & $0.44 \mathrm{c}$ & $0.21 \mathrm{~d}$ \\
\hline Peppermint & Mentha piperita & Lamiaceae & $0.59 \mathrm{c}$ & $0.49 \mathrm{~d}$ \\
\hline Spearmint & Mentha spicata & Lamiaceae & $0.94 \mathrm{c}$ & $1.67 \mathrm{bcd}$ \\
\hline Bay & Pimenta racemosa & Myrtaceae & $2.82 \mathrm{~b}$ & $0.31 \mathrm{~d}$ \\
\hline Spanish sage & Salvia officinalis & Lamiaceae & $4.86 \mathrm{~b}$ & $1.28 \mathrm{~cd}$ \\
\hline Sweet fennel & Foeniculum vulgare & Umbelliferae & $8.10 \mathrm{~b}$ & $\mathrm{ND}^{y}$ \\
\hline Tea tree & Melaleuca alternifolia & Myrtaceae & $10.07 \mathrm{~b}$ & $3.59 \mathrm{bc}$ \\
\hline Rosemary & Rosmarinus officinalis & Lamiaceae & $16.40 \mathrm{ab}$ & $10.03 \mathrm{a}$ \\
\hline Lavender & Lavandula officinalis & Lamiaceae & $28.02 \mathrm{a}$ & $4.49 \mathrm{~b}$ \\
\hline $0.1 \%$ DMSO & 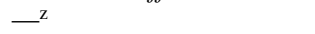 & - & ND & ND \\
\hline Zoxamide & - & - & $0.53 \mathrm{c}$ & ND \\
\hline
\end{tabular}

${ }^{\mathrm{w}} \mathrm{EC}_{50}$ is the effective concentration of essential oils for $50 \%$ inhibition of mycelial growth of $P$. capsici compared to dimethyl sulfoxide on potato dextrose agar. Mean values followed by the same letters were not significantly different based on Fisher's least significant difference test $(\alpha=0.05)$.

${ }^{x}$ Bioassay was conducted on essential oil-amended potato dextrose agar.

${ }^{\mathrm{y}} \mathrm{ND}=$ no inhibition detected.

$\mathrm{z}-=$ not applied. 
blender to form an oospore suspension. Oospores were observed under a light microscope (model DM 2500, Leica Microsystems, Buffalo Grove, IL) at $\times 40$ magnification. Four drops $(10 \mu 1 /$ drop) of each treatment were observed to enumerate oospores. The experiment was repeated.

Spore germination. Sporangial and zoospore suspensions of $P$. capsici isolates 12889 and SP98 were prepared as described in the spore production section above. One milliliter of spore suspension $\left(10^{3} \mathrm{spore} / \mathrm{ml}\right)$ was transferred into a sterile $1.8-\mathrm{ml}$ tube with $1 \mu \mathrm{l}$ of either oregano, palmarosa, red thyme, or zoxamide at final concentrations of 0.05 to $0.1,0.05$ to $0.2,0.05$ to 0.2 , and 0.02 to 0.6 $\mu \mathrm{g} / \mathrm{ml}$, respectively. DMSO at $0.1 \%$ was used as a control. Spore suspensions were incubated in the dark at $25^{\circ} \mathrm{C}$ for $12 \mathrm{~h}$. Spore germination (\%) was determined by examining 100 spores per tube under light microscopy. Four replicate tubes were used for each treatment. The experiment was repeated.

Effect of soil treatment with EOs on $P$. capsici population. A zoospore suspension of $P$. capsici isolate 12889 was prepared as described above. The method of Bowers and Locke (7) was used to conduct this trial: $50 \mathrm{~cm}^{3}$ of high porosity professional potting mix (BACCTO Michigan Peat Company, Houston, TX) was weighed after sifting through a 2-mm sieve (VWR International, West Chester, PA) and autoclaved $\left(121^{\circ} \mathrm{C}\right.$ for $1 \mathrm{~h}$ each time $)$ twice in $24 \mathrm{~h}$. Potting mix was mixed with $10 \mathrm{ml}$ of a $P$. capsici zoospore suspension at a final concentration of approximately 200 zoospores $/ \mathrm{cm}^{3}$. The infested soil was mixed with $5 \mathrm{ml}$ DMSO alone, EOs (oregano, palmarosa, red thyme at final concentrations of $0.025,0.05$, 0.1 , and $0.2 \mu \mathrm{g} / \mathrm{ml}$, respectively), or zoxamide (at a final concentration of $0.2 \mu \mathrm{g} / \mathrm{ml}$ ). Soil not infested with $P$. capsici but mixed with $0.1 \%$ DMSO was used as a control. Each soil treated was placed in four sterile $400-\mathrm{ml}$ beakers, covered with a double layer of aluminum foil, and incubated at room temperature $\left(22 \pm 1{ }^{\circ} \mathrm{C}\right)$. Five grams of soil were sampled from each beaker at $0,1,3,7,14$, and 21 days posttreatment, suspended in $10 \mathrm{ml}$ of sterile distilled water, and vortexed for $10 \mathrm{~s}$. An aliquot of $200 \mu \mathrm{l}$ of soil suspension was plated on V8 media amended with pimaricin $(10 \mu \mathrm{g} / \mathrm{ml})$, ampicillin $(250 \mu \mathrm{g} / \mathrm{ml})$, rifampicin $(10 \mu \mathrm{g} / \mathrm{ml})$, and pentachloronitrobenzene

Table 2. Effect of essential oils of oregano and red thyme on mycelial growth of Phytophthora capsici

\begin{tabular}{llcc}
\hline \multirow{2}{*}{$\begin{array}{l}\text { P. capsici } \\
\text { isolate }\end{array}$} & Fungicide & \multicolumn{2}{c}{$\mathbf{E C}_{\mathbf{5 0}}(\boldsymbol{\mu g} / \mathbf{m l})^{\mathbf{z}}$} \\
\cline { 2 - 4 } & sensitivity & Oregano EO & Red thyme EO \\
\hline R25 & Resistant to fluopicolide & $0.08 \mathrm{a}$ & $0.09 \mathrm{a}$ \\
R36 & Resistant to fluopicolide & $0.09 \mathrm{a}$ & $0.08 \mathrm{a}$ \\
R40 & Resistant to fluopicolide & $0.08 \mathrm{a}$ & $0.09 \mathrm{a}$ \\
RZ13-2 & Resistant to zoxamide & $0.06 \mathrm{ab}$ & $0.05 \mathrm{~b}$ \\
RZ3-3 & Resistant to zoxamide & $0.05 \mathrm{bc}$ & $0.05 \mathrm{~b}$ \\
12889 & Sensitive to fluopicolide & $0.03 \mathrm{c}$ & $0.07 \mathrm{ab}$ \\
& and zoxamide & &
\end{tabular}

${ }^{\mathrm{z}} \mathrm{EC}_{50}$ is the effective concentration of essential oils (EOs) for $50 \%$ inhibition of mycelial growth of $P$. capsici compared to $0.1 \%$ dimethyl sulfoxide on potato dextrose agar. Means followed by the same letters were not significantly different, determined by Fisher's least significant difference test $(\alpha=0.05)$.
(100 $\mu \mathrm{g} / \mathrm{ml}$ ) (PARP) (7) medium, with four replicate plates. The plates were incubated at room temperature $\left(22 \pm 1^{\circ} \mathrm{C}\right)$ in the dark. Colonies of $P$. capsici were counted on PARP plates after 3 days of incubation. The experiment was conducted twice.

Effect of EOs on $P$. capsici infection of and phytotoxicity to zucchini fruit and seedling emergence. Fruit infection in vitro. Zucchini (Cucurbita pepo 'Black Green') fruit were surface disinfested with $0.63 \% \mathrm{NaClO}$ for $5 \mathrm{~min}$, rinsed three times with sterile distilled water, and placed over a plastic grid in a covered plastic box with moist paper towel on the bottom to maintain high relative humidity. Three milliliters of oregano EO $(0.08$ to $0.2 \mu \mathrm{g} / \mathrm{ml})$, palmarosa EO $(0.08$ to $0.2 \mu \mathrm{g} / \mathrm{ml})$, or red thyme EO (0.05 to 0.1 $\mu \mathrm{g} / \mathrm{ml}$ ), mixed with Tween 20 (final concentration $0.1 \%$ ) and $0.1 \%$ DMSO (final concentration $0.1 \%$ ), were sprayed onto the surface of each fruit. Fruit sprayed with $3 \mathrm{ml}(0.1 \%)$ DMSO and Tween 20 mixture were used as a control. A 5-mm mycelial plug cut from the margin of a 3-day-old culture of P. capsici (isolates 12889 and SP98) was placed on the sprayed surface of the fruit. Each treatment was replicated three times. The plastic box was covered with a lid and incubated in the dark at room temperature $\left(22 \pm 1^{\circ} \mathrm{C}\right)$. After 3 days of incubation, the fruit was evaluated for infection based on the diameter of typical water-soaked lesions. The experiment was conducted twice.

Seedling emergence. In a greenhouse, seeds of common bean (Phaseolus vulgaris), beet (Beta vulgaris), carrot (Daucus carota), and pepper (Capsicum annuum) were sown in soil, immediately followed by treating the soil with clove or oregano EOs at different final concentrations, with $0.1 \%$ DMSO as a control. Seedling emergence was recorded 10 days after the treatment. In another trial, potting soil was prepared in two groups. In the first group, $900 \mathrm{~cm}^{3}$ of sterile modified potting mix (commercial potting mix was mixed with sandy soil at 1:1 ratio in volume) was infested with $300 \mathrm{~g}$ of homogenized PDA with a mycelial culture of $P$. capsici (isolate 12889); in the second group, the soil was not infested with $P$. capsici, except one control. The $900 \mathrm{~cm}^{3}$ soil mixture was treated with $90 \mathrm{ml}$ of $2 \mu \mathrm{g} / \mathrm{ml}$ oregano EO, $1 \mu \mathrm{g} / \mathrm{ml}$ red thyme EO, or $40 \mu \mathrm{g} / \mathrm{ml}$ zoxamide, and $1 \%$ DMSO, which resulted in final concentrations in soil of approximately $0.2,0.1$, and $4 \mu \mathrm{g} / \mathrm{ml}$, and $0.1 \%$, respectively. Zucchini seeds (20 seeds per treatment with three replicates) were sown in the treated soil. Emergence of zucchini seedlings was recorded 1 week after seeding. The experiment was performed twice.

Seedling infection in the greenhouse. Soil infested with $P$. capsici and treated with EOs as described in "seedling emergence" was also used in this experiment, with $P$. capsici inoculation in soil. There were five pots prepared per treatment, each treatment had four replicates, and the pots were arranged as a completely randomized design. The remaining potting mix was divided and evenly dispensed into 205.5 -cm-diameter plastic pots. Two-weekold zucchini seedlings grown in sterile potting mix in a $30 \times 40$ $\mathrm{cm}^{2}$ flat at $25^{\circ} \mathrm{C}$ in the growth chamber with $12 \mathrm{~h}$ lighting were transplanted to the pots and placed in the greenhouse at temperatures between $25^{\circ} \mathrm{C}$ (day) and $18^{\circ} \mathrm{C}$ (night). After 3, 7, 10, and 14 days posttransplanting, disease severity was evaluated as $0=$ no symptoms, 1 = slight yellow spot showing on the leaves $(<10 \%$

Table 3. Effect of essential oils on sporangia and zoospore production and germination of Phytophthora capsici

\begin{tabular}{|c|c|c|c|c|c|}
\hline \multirow[b]{2}{*}{ P. capsici isolate } & \multirow[b]{2}{*}{ Essential oil } & \multicolumn{2}{|c|}{$\mathrm{EC}_{50}$ for spore production $(\mu \mathrm{g} / \mathrm{ml})^{\mathrm{z}}$} & \multicolumn{2}{|c|}{$\mathbf{E C}_{50}$ for spore germination $(\mu \mathrm{g} / \mathrm{ml})$} \\
\hline & & Sporangium & Zoospore & Sporangium & Zoospore \\
\hline 12889 & $\begin{array}{l}\text { Red thyme } \\
\text { Oregano } \\
\text { Palmarosa }\end{array}$ & $\begin{array}{l}0.03 \mathrm{a} \\
0.02 \mathrm{a} \\
0.03 \mathrm{a}\end{array}$ & $\begin{array}{l}0.06 \mathrm{a} \\
0.07 \mathrm{a} \\
0.07 \mathrm{a}\end{array}$ & $\begin{array}{l}0.08 \mathrm{a} \\
0.08 \mathrm{a} \\
0.07 \mathrm{~b}\end{array}$ & $\begin{array}{l}0.09 \mathrm{a} \\
0.08 \mathrm{~b} \\
0.07 \mathrm{c}\end{array}$ \\
\hline SP98 & $\begin{array}{l}\text { Red thyme } \\
\text { Oregano } \\
\text { Palmarosa }\end{array}$ & $\begin{array}{l}0.05 \mathrm{a} \\
0.06 \mathrm{a} \\
0.02 \mathrm{~b}\end{array}$ & $\begin{array}{l}0.05 \mathrm{a} \\
0.02 \mathrm{c} \\
0.04 \mathrm{~b}\end{array}$ & $\begin{array}{l}0.10 \mathrm{~b} \\
0.08 \mathrm{~b} \\
0.13 \mathrm{a}\end{array}$ & $\begin{array}{l}0.11 \mathrm{a} \\
0.08 \mathrm{~b} \\
0.08 \mathrm{~b}\end{array}$ \\
\hline
\end{tabular}

${ }^{\mathrm{z}} \mathrm{EC}_{50}$ is the effective concentration for $50 \%$ inhibition of sporangia or zoospore production or germination of $P$. capsici compared to the control. Multiple comparisons were done for each $P$. capsici isolate. Mean values followed by the same letters were not significantly different based on Fisher's least significant difference test $(\alpha=0.05)$. 
area), 2 = majority of leaf area showing discolored lesion, 3 = plant significantly small or stunted, and some leaves were wilted or dried, and $4=$ plant was dead. The pathogen was reisolated from symptomatic plants and confirmed morphologically (6), and molecularly by sequencing the internal transcribed spacer (38). The experiment was conducted twice.

Data analysis. Statistical analyses were performed using the SAS package (SAS Institute, Cary, NC) version 9.2. PROC GLM (general linear model) and PROC NPAR1WAY were used to conduct analysis of variance (ANOVA) for parametric and non-
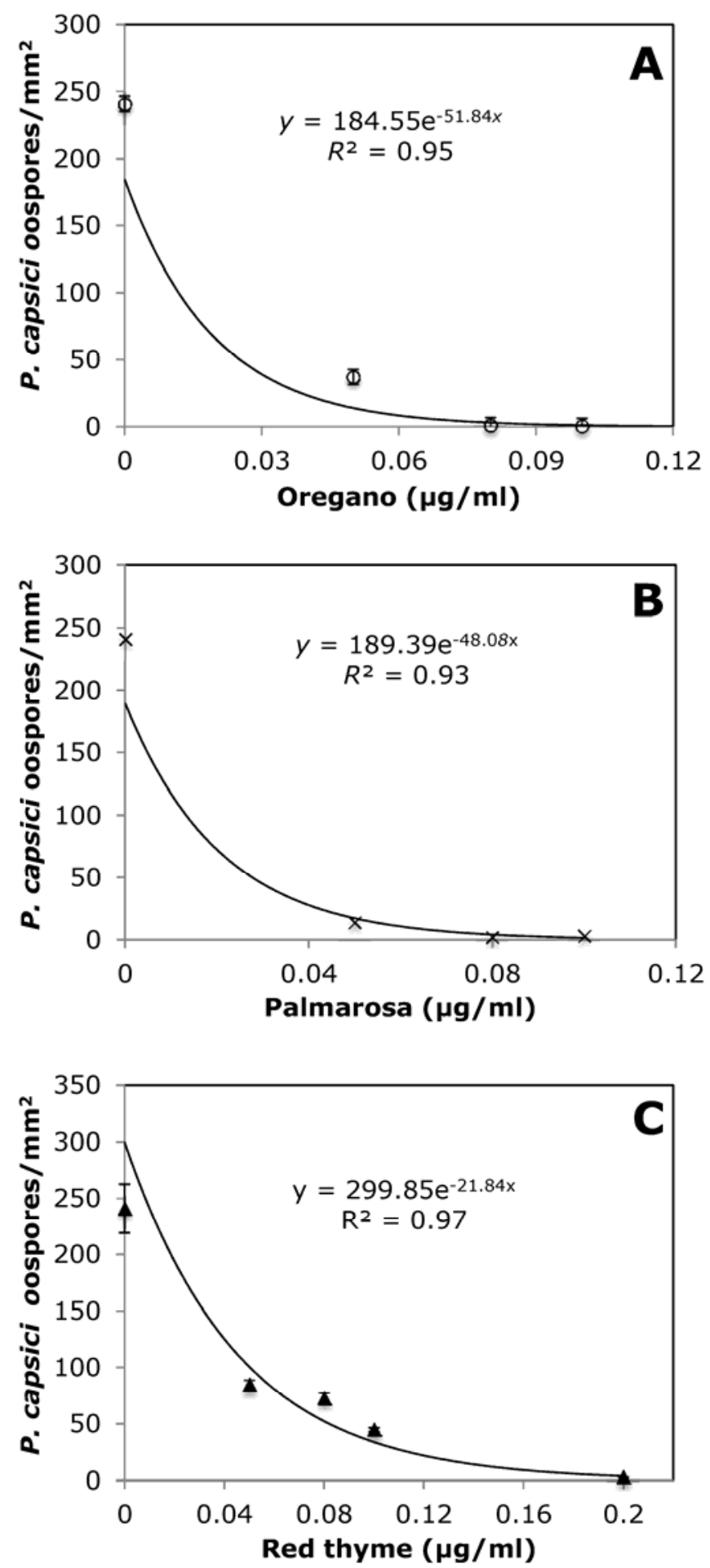

Fig. 1. Effect of $\mathbf{A}$, oregano, $\mathbf{B}$, palmarosa, and $\mathbf{C}$, red thyme essential oils on oospore production of Phytophthora capsici on V8 medium. In the regression equations, $x=$ concentration of essential oils, and $y=$ number of oospore production of $P$. capsici. Bars on each data point show standard deviation. parametric data, respectively, and PROC REG was used for linear regression for calculating $\mathrm{EC}_{50}$. All trials were set up in a randomized complete block design. Data of all trials were combined for analysis when there was no significant difference between trials or no interaction between trial and treatment. Mean values were compared using Fisher's least significant difference test at a significance level of $\alpha=0.05$. Mean values of disease severity (nonparametric data) were compared using Kruskal-Wallis test.

\section{Results}

Effect of EOs on P. capsici biology. Mycelial growth. On EOamended agar media, oregano, palmarosa, red thyme, clove bud, cinnamon leaf, and citronella java were most effective in inhibiting $P$. capsici mycelial growth, followed by peppermint and spearmint. EOs of bay, rosemary, Spanish sage, sweet fennel, tea tree, and lavender had no effect at the tested concentrations (Table 1). In volatility tests, oregano, palmarosa, and red thyme had the lowest $\mathrm{EC}_{50}$ values, followed by citronella java, clove bud, cinnamon leaf, and bay EOs; peppermint $\mathrm{EO}$ was less effective (had higher $\mathrm{EC}_{50}$ values), and the others had no effect (Table 1). The colony diameter in the control plates averaged $7 \mathrm{~cm}$. Based on these results, oregano, palmarosa and red thyme EOs were selected for further investigation. Mutant isolates of $P$. capsici resistant to zoxamide and fluopicolide were all sensitive to essential oils of oregano and red thyme in mycelial growth, although some $\mathrm{EC}_{50} \mathrm{~S}$ were significantly different $(P<0.05)$ (Table 2$)$. For example, in response to oregano, all mutant isolates had higher $\mathrm{EC}_{50}$ values than wild-type isolate 12889; while to red thyme, there was no difference between resistant and wild-type isolates (Table 2).

Sporangium and zoospore production. $\mathrm{EC}_{50}$ values for spore production were all $\leq 0.07 \mu \mathrm{g} / \mathrm{ml}$ for EOs tested (Table 3). For $P$. capsici isolate $12889, \mathrm{EC}_{50}$ values of oregano, palmarosa, and red thyme EOs showed no significant differences (between 0.02 and $0.03 \mu \mathrm{g} / \mathrm{ml}$ ) for sporangial and zoospore production. For isolate SP98, palmarosa had the lowest $\mathrm{EC}_{50}(0.02 \mu \mathrm{g} / \mathrm{ml}, P<0.05)$ in inhibiting sporangial production, and oregano EO had the lowest $\mathrm{EC}_{50}\left(\mathrm{EC}_{50}\right.$ of $\left.0.02 \mu \mathrm{g} / \mathrm{ml}, P<0.05\right)$ in inhibiting zoospore production (Table 3). Oregano, palmarosa, and red thyme EOs were all effective in inhibiting oospore production of $P$. capsici, and efficacy increased as dosage increased, showing a linear relationship between the application dose and inhibitory effect; no oospore production was observed when oregano and palmarosa EOs reached a concentration of $0.08 \mu \mathrm{g} / \mathrm{ml}$ or when red thyme EO was close to $0.16 \mu \mathrm{g} / \mathrm{ml}$ (Fig. 1).

Sporangium and zoospore germination. $\mathrm{EC}_{50}$ values of the $\mathrm{EOs}$ for $P$. capsici zoospore germination were all $\leq 0.13 \mu \mathrm{g} / \mathrm{ml}$ (Table 3 ). For $P$. capsici isolate 12889 , palmarosa EO at significantly lower $\mathrm{EC}_{50}(0.07 \mu \mathrm{g} / \mathrm{ml}, P<0.05)$ inhibited sporangial and zoospore germination, compared to oregano and red thyme EOs (Table 3). For isolate SP98, oregano and red thyme EOs were more effective at lower concentrations than palmarosa EO at inhibiting sporangial germination, but oregano and palmarosa EOs were better than red thyme EO at inhibiting zoospore germination $(P<0.05)$ (Table 3$)$.

Effect of soil treatment with EOs on $P$. capsici population. Oregano, palmarosa, and red thyme EOs effectively reduced $P$. capsici populations in soil (Fig. 2). The efficacy increased as the EO concentration or incubation time increased, supported by high correlation coefficient determinant $\left(R^{2}>0.96\right)$ of linear regression analyses. For the control, $P$. capsici population was not affected throughout the period of the study. At EO concentrations $\geq 0.1$ $\mu \mathrm{g} / \mathrm{ml}$ on day 21 of incubation, population densities of $P$. capsici were undetectable (Fig. 2).

Effect of EOs on P. capsici infection of and toxicity to plants. Fruit infection in vitro. Zucchini fruits inoculated with $P$. capsici were fully covered by mycelia on the control. A low rate of zoxamide $(2 \mu \mathrm{g} / \mathrm{ml})$ had no effect on preventing the infection, but at a higher rate $(4 \mu \mathrm{g} / \mathrm{ml})$ it partially inhibited the infection based on lesion size and disease severity. Oregano EO at $0.2 \mu \mathrm{g} / \mathrm{ml}$, palmarosa at $0.2 \mu \mathrm{g} / \mathrm{ml}$, and red thyme at $0.1 \mu \mathrm{g} / \mathrm{ml}$ all significantly suppressed infection by $P$. capsici. The effects of EOs at lower ap- 
plication rates were not significant in preventing infection (Table 4). The pathogen was isolated from symptomatic fruit and P. capsici confirmed by morphological and molecular techniques.

Seedling emergence. Without $P$. capsici infestation in soil, clove EO inhibited the seedling emergence of beet at $0.1 \mu \mathrm{g} / \mathrm{ml}$, but had no effect at $0.08 \mu \mathrm{g} / \mathrm{ml}$; all of the seedling emergence of bean, carrot, and pepper was not affected by clove EO at any tested concentrations. Oregano EO significantly inhibited seedling emergence of bean at 0.05 and $0.1 \mu \mathrm{g} / \mathrm{ml}$; beet, carrot, and pepper seedling emergence was not affected by oregano EO at concentrations of 0.1 $\mu \mathrm{g} / \mathrm{ml}$ (Table 5). In the trial with P. capsici inoculated in soil (Fig. 3 ), seedling emergence was significantly reduced by $P$. capsici.
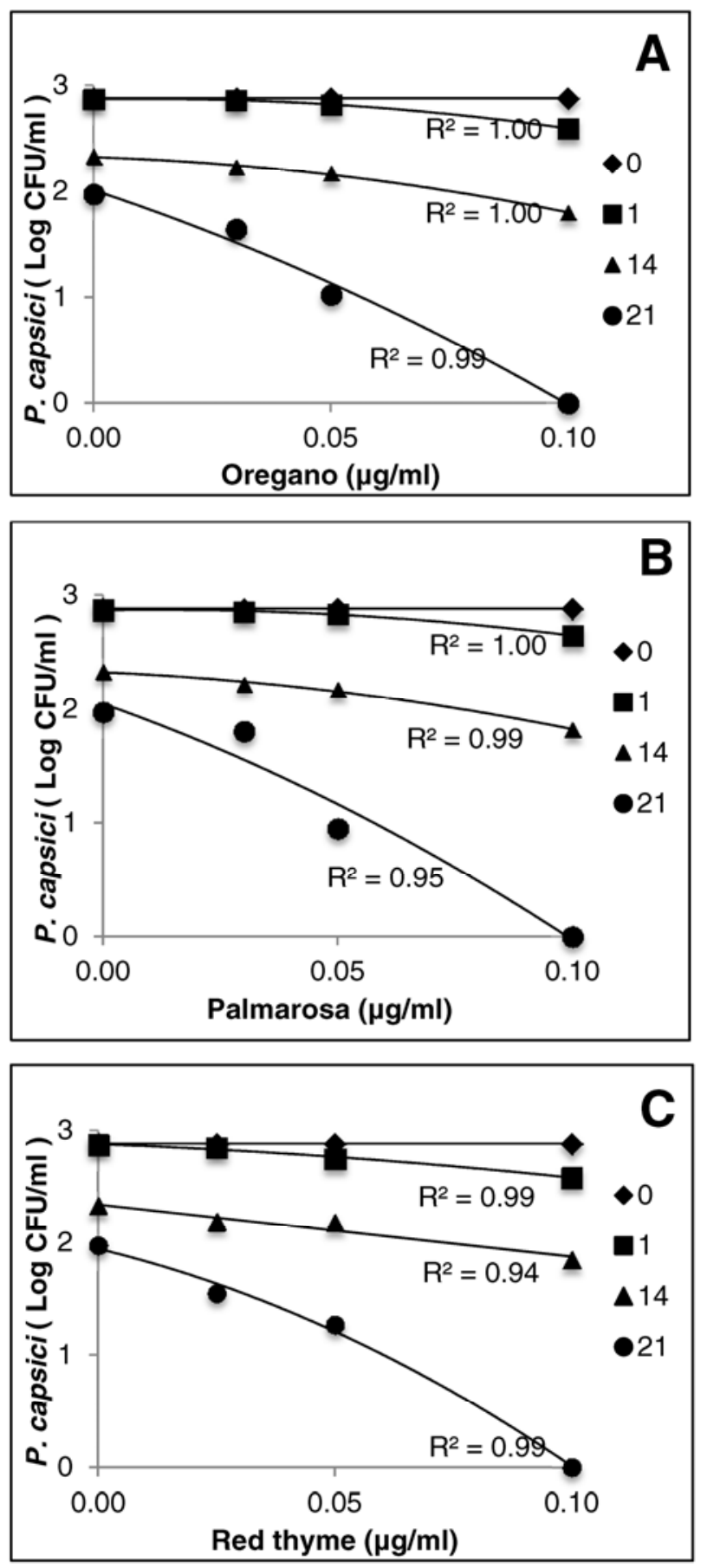

Fig. 2. Effect of the essential oils of $\mathbf{A}$, oregano, $\mathbf{B}$, palmarosa, and $\mathbf{C}$, red thyme on soil populations of Phytophthora capsici at different incubation times $(0,1,14$, and 21 days), and concentration $0.05 \mu \mathrm{g} / \mathrm{ml}$. $R^{2}$ values of regressions were given for each time-period (day) of incubation, except day 0 .
Oregano, red thyme EOs, and zoxamide all reduced seedling emergence, but the reduction was significantly less than $P$. capsiciinfested soil. Increasing the concentration (at between 0.05 and 0.2 $\mu \mathrm{g} / \mathrm{ml}$ ) of oregano EO had lower seedling emergence rate. Emergence was highest when the soil was treated with oregano at 0.05 $\mu \mathrm{g} / \mathrm{ml}$ or red thyme at $0.2 \mu \mathrm{g} / \mathrm{ml}$ (Fig. 3). Therefore, oregano had a negative impact on zucchini seedling emergence, but red thyme had no such effect.

Seedling infection in the greenhouse. All zucchini seedlings were dead in P. capsici-infested and DMSO-treated soil. More than $90 \%$ of seedlings (5 seedlings per treatment) were healthy when the $P$. capsici-infested soil was treated with $0.2 \mu \mathrm{g} / \mathrm{ml}$ oregano and red thyme EOs; and there was no difference in disease severity between oregano EO and red thyme EO treatments (Fig. 4).

\section{Discussion}

We have demonstrated that some plant EOs, specifically oregano, palmarosa, and red thyme, are effective for control of $P$. capsici in vitro and in vivo. The product can be used for soil treatment to reduce soil population of $P$. capsici and thus reduce the incidence of plant infection. The results of this study provide critical baseline information for potential field application of EOs, in addition to a limited number of previously reported data on $P$. capsici $(32,39)$. In these previous studies conducted for $P$. capsici suppression, EOs were usually extracted under laboratory conditions from various parts of plants and from few species of plants $(2,10,32,39)$, which may have contributed to the varied efficacies. Therefore, using commercially available EOs extracted using a standard protocol may give a consistent and repeatable result similar to this study. This study shows that EOs can effectively inhibit the growth

Table 4. Effect of essential oils on controlling Phytophthora capsici (isolate 12889) infection on zucchini fruit

\begin{tabular}{lcc}
\hline $\begin{array}{l}\text { Treatment } \\
\text { (application rate in } \boldsymbol{\mu g} / \mathbf{m l})^{\mathbf{x}}\end{array}$ & Lesion size $(\mathbf{c m}) \mathbf{y}^{\mathbf{y}}$ & Disease severity $^{\mathbf{z}}$ \\
\hline DMSO (0.1\% in volume) & $4.7 \mathrm{a}$ & $2.7 \mathrm{a}$ \\
Zoxamide (2) & $4.9 \mathrm{a}$ & $2.7 \mathrm{a}$ \\
Zoxamide (4) & $2.6 \mathrm{~b}$ & $1.0 \mathrm{~b}$ \\
Palmarosa (0.08) & $3.1 \mathrm{ab}$ & $1.8 \mathrm{a}$ \\
Palmarosa (0.2) & $0.0 \mathrm{c}$ & $0.0 \mathrm{~b}$ \\
Oregano (0.08) & $3.3 \mathrm{ab}$ & $2.0 \mathrm{a}$ \\
Oregano (0.2) & $0.0 \mathrm{c}$ & $0.0 \mathrm{~b}$ \\
Red thyme (0.05) & $3.6 \mathrm{ab}$ & $2.0 \mathrm{a}$ \\
Red thyme (0.1) & $0.0 \mathrm{c}$ & $0.0 \mathrm{~b}$
\end{tabular}

${ }^{x}$ Fruit was sprayed either with dimethyl sulfoxide (DMSO), oregano essential oil, red thyme essential oil, or zoxamide at various concentrations shown in the table, followed by applying three 5-mm plugs of $P$. capsici from potato dextrose agar on each fruit.

${ }^{\mathrm{y}}$ Lesion size was the average of lesion diameter from P. capsici infection. Mean values followed by the same letters were not significantly different based on Fisher's least significant difference test $(\alpha=0.05)$.

${ }^{\mathrm{z}}$ Disease severity was rated as: $0=$ no symptoms; $1=$ visible initial mycelial development; 2 = thin layer of mycelial patch; and $3=$ thick layer and white-colored mycelial colony developed. Mean values followed by the same letters were not significantly different based on Kruskal-Wallis test.

Table 5. Effects of clove and oregano essential oils on the seedling emergence (\%) of common bean (Phaseolus vulgaris), beet (Beta vulgaris), carrot (Daucus carota), and pepper (Capsicum annuum)

\begin{tabular}{lllcc}
\hline Essential oil $(\boldsymbol{\mu g} / \mathbf{m l})$ & Bean $^{\mathbf{z}}$ & Beet & Carrot & Pepper \\
\hline Clove $(0.08)$ & $81.4 \mathrm{ab}$ & $31.1 \mathrm{ab}$ & 61.1 & 58.9 \\
Clove $(0.1)$ & $78.3 \mathrm{ab}$ & $24.4 \mathrm{~b}$ & 46.7 & 52.2 \\
Nontreated & $86.0 \mathrm{a}$ & $47.8 \mathrm{a}$ & 68.9 & 65.6 \\
Oregano $(0.05)$ & $72.6 \mathrm{~b}$ & $37.8 \mathrm{ab}$ & 64.4 & 65.6 \\
Oregano $(0.1)$ & $54.9 \mathrm{c}$ & $32.2 \mathrm{ab}$ & 52.2 & 56.7 \\
\hline
\end{tabular}

${ }^{\mathrm{z}}$ Means of emergence rate were separated by multiple range comparisons using Fisher's least square difference test at $\alpha=0.05$. Mean values followed by the same letters are not significantly different. 
of $P$ capsici isolates that are resistant to fluopicolide or zoxamide. This implies that EOs may be an alternative to synthetic fungicides for resistant management strategies.

Oregano, palmarosa, and red thyme affected all stages of the $P$. capsici life cycle: production and germination of sporangia and zoospores, oospore production, and mycelial growth. The EOs were found to be fungicidal rather than fungistatic materials. Soil populations of $P$. capsici were significantly reduced by applying oregano or red thyme EO, resulting in suppression of damping-off symptoms in zucchini seedlings. Low $\mathrm{EC}_{50}$ values correlated with a high level of efficacy in terms of antimicrobial activity and disease incidence reduction. EOs from clove bud, cinnamon leaf, and citronella java also inhibited $P$. capsici, but the volatiles had much higher $\mathrm{EC}_{50}$ values than oregano, palmarosa, and red thyme. This is the first study to show that palmarosa EO effectively controls $P$. capsici based on in vitro pathogenicity tests, and that oregano, palmarosa, and red thyme reduced $P$. capsici populations in soil and disease development in zucchini.

EOs are composed of a range of bioactive compounds, such as alkaloids, flavonoids, phenols, quinone saponins, sterols, and tan-

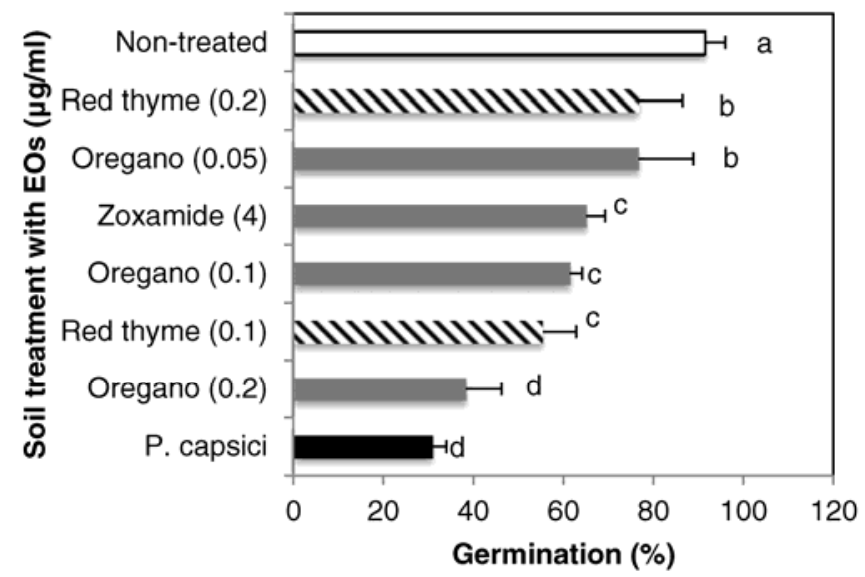

Fig. 3. Effect of the essential oils (EOs) of oregano and red thyme on zucchini seedling emergence. For control, soil was either infested with Phytophthora capsici (PC) mycelial culture blended in or none; for treatments, soil was not infested with $P$. capsici, but treated with oregano EO, red thyme EO, and zoxamide at various final concentrations. Zucchini seeds (20 seeds per treatment) were sown immediately after soil treatment. Bars of each column are standard deviation, and means of emergence rate were separated by Fisher's least square difference multiple range comparisons method at $\alpha=0.05$. Mean values followed by the same letters are not significantly different.

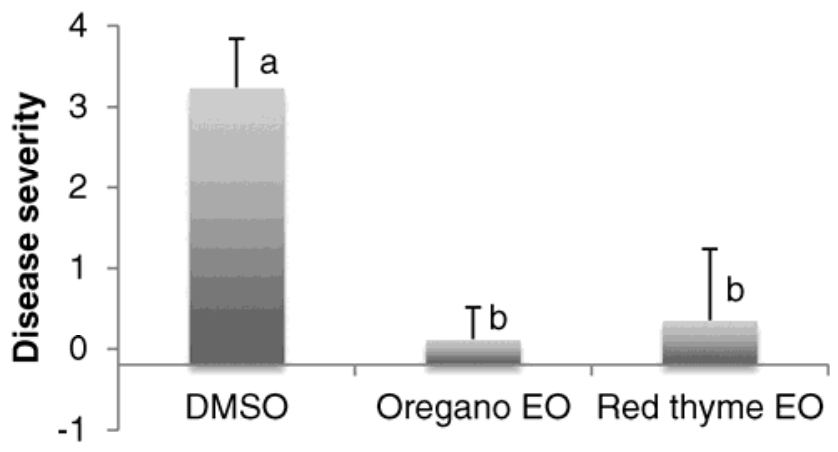

Soil treatment

Fig. 4. Effect of the essential oils (EOs) of oregano and red thyme, at $0.2 \mu \mathrm{g} / \mathrm{ml}$, on the severity of zucchini seedling damping-off in the greenhouse. DMSO ( $0.1 \%$ in volume) was used as control. Disease severity was evaluated as: $0=$ no symptoms; $1=$ slight yellow spot showing on the leaves $(<10 \%$ area); $2=$ majority of leaf area showing discolored lesion; $3=$ plant significantly small or stunted, and some leaves wilted or dried; and $4=$ plant was dead. Means were separated by Kruskal-Wallis test at $\alpha=$ 0.05 . Bars over each column are standard deviation, and means of disease severity followed by the same letters are not significantly different. nins, that are associated with antimicrobial activities $(4,8,20,34)$. Solyu et al. (34), in an examination of EO activity against $P$. infestans, found that oregano contains 24 compounds and thyme contains 16 compounds. Their results indicated the major active compounds were carvacrol and $p$-cymene for both EOs, with the addition of linalool and $c$-terpinene for red thyme. Some of the same compounds were shown by Al-Reza et al. (1) to inhibit $P$. capsici in vitro. These compounds may have several invasive targets for inhibition, such as attacking cell walls and cell membranes, that result in affecting the permeability and release of intracellular constituents, in addition to interfering with membrane function (1). The lipophilic properties of EO components may help the oil to penetrate the plasma membrane, affect enzymatic activities, and deregulate cell wall synthesis (30). At higher doses, EOs containing these compounds can lyse the cell and could result in the inhibition of growth of $P$. capsici, as observed under SEM.

Phytotoxicity may be a concern when EOs are applied to plants or soil. Oregano EO inhibits plant seedling emergence when applied just before or immediately after seeding. This could cause problems to plant production if oregano EO is used. However, such a problem can be avoided if appropriate strategies are used, for example, using a low rate and extending the interval between EO application and planting. In this study, when zucchini was planted 3 weeks after the soil was treated with EOs, there was no negative effect on plant growth. Fortunately, some EOs, such as red thyme EO, had no impact on plant seedling emergence and seedling growth in our study, and not all seed types were affected at emergence by the EOs. Therefore, selecting an appropriate EO for a specific host is one option to avoid phytotoxicity concerns.

EOs can be used and implemented in IPM strategies or organic production, as shown in other disease systems (19). As EOs contain volatiles that inhibit plant pathogens, they can be used as soil fumigants (20). According to the Environmental Protection Agency (EPA), no risks or adverse effects to humans or the environment have been found for EOs, so they can be easily registered as a pesticides (EPA, website). Moreover, EOs can be used for treating soil before planting, resulting in a flexible production schedule. However, whether the pathogen will be in a vulnerable stage when the product is applied earlier needs to be determined in future studies, because most pathogens are in a dormant or overwintering stage before conditions become favorable for infection. High-scale industrial production can help to reduce the cost, or to synthesize the active compounds if they are well characterized. For example, the commercial product Thymol, a volatile compound originally identified from Thymus spp., is an agricultural grade product that has been produced synthetically to control bacterial diseases and is affordable (19). However, it may not have the same effect as a mixture of compounds in the EO. We envision that EOs can be used as a "green pesticide" in organic production in the future. They also have potential in fungicide resistance management strategies when alternated or tank mixed with current fungicides.

\section{Acknowledgments}

This project was partially supported by United States Department of Agriculture Specialty Crop Research Initiative program (NIFA grant no. 2008-5118004881) and the Michigan Vegetable Council. The authors are grateful to Elizabeth Kelley for initiating the project and conducting some pilot work, and Linda Hanson, Noah Rosenzwieg, and Sheila Linderman for a critical review of the manuscript

\section{Literature Cited}

1. Al-Reza, S. M., Atiqur, R., Yunus, A., and Kang, S. 2010. Inhibition of plant pathogens in vitro and in vivo with essential oil and organic extracts of Cestrum nocturnum L. Pestic. Biochem. Phys. 96:86-92.

2. Atiqur, R., Hossain, M. A., and Kang, S. 2010. Control of phytopathogenic fungi by the essential oil and methanolic extracts of Erigeron ramosus (Walt.) B.S.P. Eur. J. Plant Pathol. 128:211-219.

3. Babadoost, M. 2000. Outbreak of Phytophthora foliar blight and fruit rot in processing pumpkin fields in Illinois. Plant Dis. 84:1345.

4. Bajpai, V. K., Lee, T., and Kang, S. 2009. Chemical composition and in vitro control of agricultural plant pathogens by the essential oil and various extracts of Nandina domestica Thunb. J. Sci. Food Agric. 89:109-116.

5. Bassole, I. H. N., Ouattara, A. S., Nebie, R., Ouattara, C. A. T., Kabore, Z. 
I., and Traore, S. A. 2003. Chemical composition and antibacterial activities of the essential oils of Lippia chevalieri and Lippia multiflora from Burkina Faso. Phytochemistry 62:209-212.

6. Bi, Y., Cui, X. L., Lu, X. H., Cai, M., Liu, X. L., and Hao, J. J. 2011. Baseline sensitivity of natural population and resistance of mutants in Phytophthora capsici to zoxamide. Phytopathology 101:1104-1111.

7. Bowers, J. H., and Locke, J. C. 2004. Effect of formulated plant extracts and oils on population density of Phytophthora nicotianae in soil and control of Phytophthora blight in the greenhouse. Plant Dis. 88:11-16.

8. Burt, S. 2004. Essential oils: Their antibacterial properties and potential applications in foods - a review. Int. J. Food Microbiol. 94:223-253.

9. Cavalca, P. A. M., Lolis, M., Reis, B., and Bonato, C. M. 2010. Homeopathic and larvicide effect of Eucalyptus cinerea essential oil against Aedes aegypti. Braz. Arch. Biol. Technol. 53:835-843.

10. Dan, Y., Liu, H. Y., Gao, W. W., and Chen, S. L. 2010. Activities of essential oils from Asarum heterotropoides var. mandshuricum against five phytopathogens. Crop Prot. 29:295-299.

11. Del Rio, J. A., Arcas, M. C., Benavente-Garcia, O., and Ortuno, A. 1998. Citrus polymethoxylated flavones can confer resistance against Phytophthora citrophthora, Penicillium digitatum, and Geotrichum species. J. Agric. Food Chem. 46:4423-4428.

12. Erwin, D. C., and Ribeiro, O. K. 1996. Phytophthora Diseases Worldwide. American Phytopathological Society, St. Paul, MN.

13. Foster, J. M., and Hausbeck, M. K. 2010. Managing Phytophthora crown and root rot in bell pepper using fungicides and host resistance. Plant Dis. 94:697-702.

14. Gorski, R., Sobieralski, K., Siwulski, M., and Gora, K. 2010. Effect of selected natural essential oils on in vitro development of fungus Trichoderma harzianum found in common mushroom (agaricus bisporus) cultivation. Ecol. Chem. Eng. S-Chemia I Inzynieria Ekologiczna S 17:69-77.

15. Gwinn, K. D., Ownley, B. H., Greene, S. E., Clark, M. M., Taylor, C. L., Springfield, T. N., Trently, D. J., Green, J. F., Reed, A., and Hamilton, S. L. 2010. Role of essential oils in control of Rhizoctonia damping-off in tomato with bioactive Monarda herbage. Phytopathology 100:493-501.

16. Hausbeck, M. K., and Lamour, K. H. 2004. Phytophthora capsici on vegetable crops: Research progress and management challenges. Plant Dis. 88:1292-1303

17. Isman, M. B. 2004. Plant essential oils as green pesticides for pest and disease management. Agric. Appl. Green Chem. 887:41-51.

18. Ji, P., Momol, M. T., Olson, S. M., Pradhanang, P. M., and Jones, J. B. 2005. Evaluation of thymol as biofumigant for control of bacterial wilt of tomato under field conditions. Plant Dis. 89:497-500.

19. Ji, P. S., Momol, M. T., Rich, J. R., Olson, S. M., and Jones, J. B. 2007. Development of an integrated approach for managing bacterial wilt and root-knot on tomato under field conditions. Plant Dis. 91:1321-1326.

20. Kim, J., Lee, Y. S., Lee, S. G., Shin, S. C., and Park, I. K. 2008. Fumigant antifungal activity of plant essential oils and components from West Indian bay (Pimenta racemosa) and thyme (Thymus vulgaris) oils against two phytopathogenic fungi. Flavour Frag. J. 23:272-277.

21. Kiran, O. E., Ilcim, A., and Digrak, M. 2010. Antifungall activity against Phytophthora capsici Leon which causes root neck burn in pepper around Kahramanmaras. Asian J. Chem. 22:468-474.

22. Lamour, K. H., and Hausbeck, M. K. 2000. Mefenoxam insensitivity and the sexual stage of Phytophthora capsici in Michigan cucurbit fields. Phytopathology 90:396-400.

23. Lee, Y. S., Kim, J., Shin, S. C., Lee, S. G., and Park, I. K. 2008. Antifungal activity of Myrtaceae essential oils and their components against three phytopathogenic fungi. Flavour Frag. J. 23:23-28.

24. Lu, X. H., Hausbeck, M. K., Liu, X. L., and Hao, J. J. 2011. Wild type sensitivity and mutation analysis for resistance risk to fluopicolide in Phytophthora capsici. Plant Dis. 95:1535-1541.

25. Macedo, I. T. F., Bevilaqua, C. M. L., de Oliveira, L. M. B., CamurcaVasconcelos, A. L. F., Vieira, L. D., Oliveira, F. R., Queiroz, E. M., Tome, A. D., and Nascimento, N. R. F. 2010. Anthelmintic effect of Eucalyptus staigeriana essential oil against goat gastrointestinal nematodes. Vet. Parasit. 173:93-98.

26. Mercier, J., and Manker, D. C. 2005. Biocontrol of soil-borne diseases and plant growth enhancement in greenhouse soilless mix by the volatileproducing fungus Muscodor albus. Crop Prot. 24:355-362.

27. Olanya, O. M., and Larkin, R. P. 2006. Efficacy of essential oils and biopesticides on Phytophthora infestans suppression in laboratory and growth chamber studies. Biocontrol Sci. Technol. 16:901-917.

28. Quintanilla, P., Rohloff, J., and Iversen, T. H. 2002. Influence of essential oils on Phytophthora infestans. Potato Res. 45:225-235.

29. Rahman, A., Hossain, M. A., and Kang, S. C. 2010. Control of phytopathogenic fungi by the essential oil and methanolic extracts of Erigeron ramosus (Walt.) BSP. Eur. J. Plant Pathol. 128:211-219.

30. Rasooli, I., Rezaei, M. B., and Allameh, A. 2006. Growth inhibition and morphological alterations of Aspergillus niger by essential oils from Thy mus eriocalyx and Thymus x-porlock. Food Control 17:359-364.

31. Ristaino, J. B., and Johnston, S. A. 1999. Ecologically based approaches to management of Phytophthora blight on bell pepper. Plant Dis. 83:1080-1089.

32. Silva, D. M. M. H., and Bastos, C. N. 2007. Antifungal activity of essentia oils of Piper species against Crinipellis perniciosa, Phytophthora palmivora and Phytophthora capsici. Fitopatol. Bras. 32:143-145.

33. Soylu, E. M., Kurt, S., and Soylu, S. 2010. In vitro and in vivo antifungal activities of the essential oils of various plants against tomato grey mould disease agent Botrytis cinerea. Int. J. Food Microbiol. 143:183-189.

34. Soylu, E. M., Soylu, S., and Kurt, S. 2006. Antimicrobial activities of the essential oils of various plants against tomato late blight disease agent Phytophthora infestans. Mycopathologia 161:119-128.

35. Walter, M., Jaspers, M. V., Eade, K., Frampton, C. M., and Stewart, A 2001. Control of Botrytis cinerea in grape using thyme oil. Australas. Plant Pathol. 30:21-25.

36. Wang, J. H., Liu, H., Zhao, J. L., Gao, H. F., Zhou, L. G., Liu, Z. L., Chen, Y. Q., and Sui, P. 2010. Antimicrobial and antioxidant activities of the roo bark essential oil of Periploca sepium and its main component 2-hydroxy-4methoxybenzaldehyde. Molecules 15:5807-5817.

37. Wang, S. Y., Yang, C. W., Liao, J. W., Zhen, W. W., Chu, F. H., and Chang, S. T. 2008. Essential oil from leaves of Cinnamomum osmophloeum acts as a xanthine oxidase inhibitor and reduces the serum uric acid levels in oxonate-induced mice. Phytomedicine 15:940-945.

38. White, T. J., Bruns, T., Lee, S., and Taylor, J. W. 1990. Amplification and direct sequencing of fungal ribosomal RNA genes for phylogenetics. Pages 315-322 in: PCR Protocols: A Guide to Methods and Applications, M. A Innis, D. H. Gelfand, J. J. Sninsky, and T. J. White, ed. Academic Press, New York.

39. Yegen, O., Unlu, A., and Berger, B. M. 1998. Use and side effects on the soil microbial activity of the essential oil from Thymbra spicata to control pepper blight Phytophthora capsici. Z. Pflanzenk. Pflanzen. 105:602-610.

40. Yesil-Celiktas, O., Kocabas, E. E. H., Bedir, E., Sukan, F. V., Ozek, T., and Baser, K. H. C. 2007. Antimicrobial activities of methanol extracts and essential oils of Rosmarinus officinalis, depending on location and seasonal variations. Food Chem. 100:553-559. 